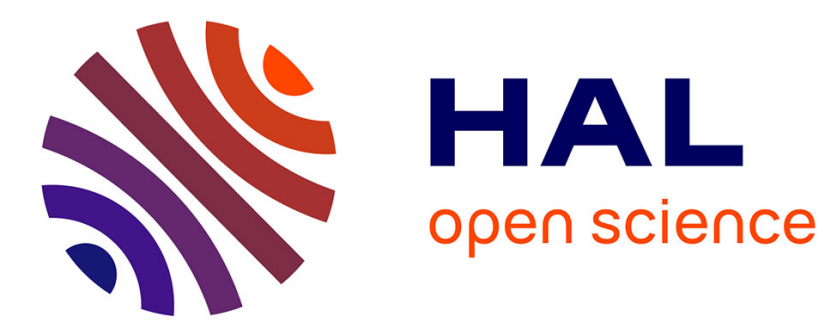

\title{
Global agronomy, a new field of research. A review
}

\author{
David Makowski, Thomas Nesme, François Papy, Thierry Doré
}

\section{To cite this version:}

David Makowski, Thomas Nesme, François Papy, Thierry Doré. Global agronomy, a new field of research. A review. Agronomy for Sustainable Development, 2014, 34 (2), pp.293-307. 10.1007/s13593013-0179-0 . hal-01173290

\section{HAL Id: hal-01173290 \\ https://hal.science/hal-01173290}

Submitted on 2 Aug 2019

HAL is a multi-disciplinary open access archive for the deposit and dissemination of scientific research documents, whether they are published or not. The documents may come from teaching and research institutions in France or abroad, or from public or private research centers.
L'archive ouverte pluridisciplinaire HAL, est destinée au dépôt et à la diffusion de documents scientifiques de niveau recherche, publiés ou non, émanant des établissements d'enseignement et de recherche français ou étrangers, des laboratoires publics ou privés. 


\section{Agronomy for Sustainable Development Global agronomy, a new field of research. A review. --Manuscript Draft--}

Manuscript Number:

Full Title:

Article Type:

Keywords:

Corresponding Author:
ASDE-D-13-00073R2

Global agronomy, a new field of research. A review.

Review Article

Agronomy; Food security; global changes; modeling

David Makowski

FRANCE

Corresponding Author Secondary Information:

Corresponding Author's Institution:

Corresponding Author's Secondary Institution:

First Author:

David Makowski

First Author Secondary Information:

Order of Authors:

David Makowski

Thomas Nesme

François Papy

Thierry Doré

Order of Authors Secondary Information:

Abstract:

The global impact of agriculture has recently become a major research topic, stressed by the rapid growth of the world population. Agriculture management is indeed influencing the quality of water, air, soil and biodiversity at the global scale. The main agricultural challenges have already been reviewed, but these reviews did not discuss in detail the adaptations of agricultural techniques to global issues and the research challenges for agronomy. Here we propose a research planning for global agronomy including the following advices. Agronomists should update their research objects, methods and tools to address global issues. Yield trends and variations among various regions should be analyzed to understand the sources of these variations. Crop model simulations should be upscaled to estimate potential yields and to assess the effect of climate change and resource scarcity at the global scale. Advanced methods should analyze output uncertainty of complex models used at a global scale. Indeed various global models are actually used, but these models are too complex and the output uncertainty is difficult to analyze. The meta-analysis of published data is a promising approach for addressing global issues, though meta-analysis must be applied carefully with appropriate techniques. Finally, global datasets on the performance and environmental impact of cropping systems should be developed to allow agronomists to identify promising cropping systems.

\section{Author Comments:}

\section{Dear Editor,}

We thank you again for taking time to consider this revision and giving us the opportunity to revise the paper. All the suggestions made by the Editor-in-chief have been taken into account.

We hope you will consider that your comments were appropriately addressed.

Sincerely yours,

David Makowski (on behalf of the co-authors) 
- Pourriez-vous, s'il vous plait, insérer une photo couleur dans l'introduction ?

Nous pensions que la carte du monde mentionnée en introduction pourrait faire office de photo mais, comme cela ne semble pas être le cas, une photo illustrant la croissance démographique a été ajoutée dans la version révisée de l'article (Figure 1).

- Etes-vous d'accord avec le titre et le résumé suivants : Global Agronomy, a new era. A review The global impact of agriculture has...

L'idée de raccourcir le titre nous parait bonne mais nous souhaitons insister surtout sur le nouveau champs disciplinaire, plus que sur la nouvelle ère. Nous proposons donc: "Global agronomy, a new field of research. A review". Nous nous demandons toutefois si le terme "Global agronomy" sera aussi percutant en anglais qu'en français.

Le résumé proposé par l'éditeur a été intégré à l'article avec quelques modifications mineures. 


\section{Réponse à l'éditeur}

- Pourriez-vous, s'il vous plait, insérer une photo couleur dans
l'introduction?

Nous pensions que la carte du monde mentionnée en introduction pourrait faire office de photo mais, comme cela ne semble pas être le cas, une photo illustrant la croissance démographique a été ajoutée dans la version révisée de l'article (Figure 1).

- Etes-vous d'accord avec le titre et le résumé suivants : Global

Agronomy, a new era. A review The global impact of agriculture has...

L'idée de raccourcir le titre nous parait bonne mais nous souhaitons insister surtout sur le nouveau champs disciplinaire, plus que sur la nouvelle ère. Nous proposons donc:

"Global agronomy, a new field of research. A review". Nous nous demandons toutefois si le terme "Global agronomy" sera aussi percutant en anglais qu'en français.

Le résumé proposé par l'éditeur a été intégré à l'article avec quelques modifications mineures. 


\section{Global agronomy, a new field of research. A review.}

2

3 David Makowski ${ }^{1,2}$, Thomas Nesme ${ }^{3,4}$, François Papy ${ }^{5,6}$, Thierry Dorée ${ }^{2,1}$

4

$5{ }^{1}$ INRA, UMR 211 Agronomie, F-78850 Thiverval-Grignon, France

$6{ }^{2}$ AgroParisTech, UMR 211 Agronomie, F-78850 Thiverval-Grignon, France

$7 \quad{ }^{3}$ Univ. Bordeaux, UMR 1220 TCEM, F-33175 Gradignan, France

$8{ }^{4}$ INRA, UMR 1220 TCEM, F-33882 Villenave d'Ornon, France

$9{ }^{5}$ INRA, UMR 1048 SADAPT, BP 01, Thiverval-Grignon, France

$10{ }^{6}$ AgroParisTech, UMR 1048 SADAPT, BP 01, Thiverval-Grignon, France

David Makowski

Fax: 33130815425 
The global impact of agriculture has recently become a major research topic, stressed by the rapid growth of the world population. Agriculture management is indeed influencing the quality of water, air, soil and biodiversity at the global scale. The main agricultural challenges have already been reviewed, but these reviews did not discuss in detail the adaptations of agricultural techniques to global issues and the research challenges for agronomy. Here we propose a research planning for global agronomy including the following advices. Agronomists should update their research objects, methods and tools to address global issues. Yield trends and variations among various regions should be analyzed to understand the sources of these variations. Crop model simulations should be upscaled to estimate potential yields and to assess the effect of climate change and resource scarcity at the global scale. Advanced methods should analyze output uncertainty of complex models used at a global scale. Indeed various global models are actually used, but these models are too complex and the output uncertainty is difficult to analyze. The meta-analysis of published data is a promising approach for addressing global issues, though meta-analysis must be applied carefully with appropriate techniques. Finally, global datasets on the performance and environmental impact of cropping systems should be developed to allow agronomists to identify promising cropping systems. 


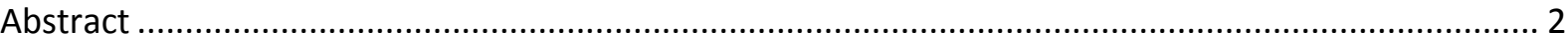

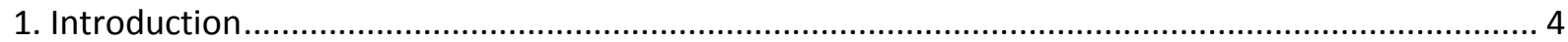

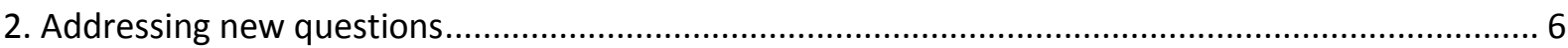

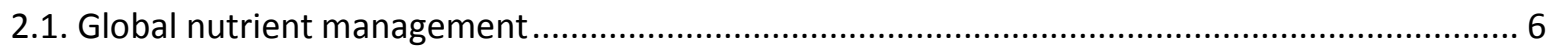

47 3. Current knowledge and methods in agronomy: their utility and limitations for addressing global 
61

62

63

64

65

66

67

68

69

\section{Introduction}

The impact of agriculture has long been studied at the local scale by agronomists. Many experiments have been carried out to assess the effect of one or a small number of aspects of crop management (e.g. soil tillage, fertilizer rates, etc.) on one or a small number of variables of interest (e.g. yield, soil characteristics). Experiments have also been carried out to compare and assess cropping systems at the field and, in a few cases, farm scales (Vereijken 1997). Since the late 1980s, modeling tools have been used to optimize agricultural practices at the field and farm scales and, in few cases, at the regional or continental scales (van Ittersum et al. 1998; de Wit et al. 1988).

However, the effect of agricultural activities at the global scale has recently become an important research topic. This shift is due to the large growth of the world population (Spiertz 2012) (Figure 1) and increasing concerns about air, soil and water quality, the fate of biodiversity and resource management (Mueller et al. 2012; Tscharntke et al. 2012). Agriculture has to deal with greater and emerging challenges relating to food security and its impact on the global environment. The effect of nitrogen fertilization on greenhouse gas emissions (Philibert et al. 2013), the global phosphorus resource depletion, the estimation of future crop yield trends (Lobell and Burke 2010), yield gap analysis at the global scale (Mueller et al. 2012), and the impact of invasive pests (Dupin et al. 2011) are examples of research topics that have recently emerged and are now studied by major agricultural research institutes. The results of these new investigations are frequently used in prospective studies on food security (Paillard et al. 2010) and global environmental issues, such as global nutrient flows (Gruber and Galloway 2008), global warming (Parry et al. 2007), and biodiversity loss (Tscharntke et al. 2012). Prospective studies, such as Agrimonde (Paillard et al. 2010) are based on diverse scenarios based on different hypotheses concerning future food demand, food production levels and impacts of agriculture on the environment. Scenarios about future cropping 
systems are therefore required in prospective studies, and agronomists are now frequently asked to provide data on future agricultural practices, and on future levels of crop productions (Figure 2).

These recent changes present agronomy with both opportunities and challenges. Agronomists have the opportunity to deal with important global issues and to become important players in groups of scientists working on food security and environment and resource protection. However, they will also face major challenges if they are to provide a useful contribution to the current research on global issues. Agronomists need to jump from references established for crop production and the environmental impact of agriculture at local scales to new references for use at larger scales. They also need to find effective ways to communicate their results to other scientists (particularly economists and climatologists), developing models simulating the impact of agricultural activities at the regional, continental and global scales.

Several reviews on global food security have recently been published (Spiertz 2012; Tscharntke et al. 2012). They present the principal challenges to be faced by agriculture in the next few decades. However, they do not discuss the ways in which current agricultural research methods would need to be adapted to deal with global issues. We present here a research agenda for global agronomy. We show that agronomists need to reconsider their research objectives and to update their research tools before addressing global issues. Below, we present examples of topics that should be investigated at the global scale. We then review the types of data already produced by agronomists and assess the value of these data for studying the effect of agricultural activities at the global scale. Finally, we present various methods for addressing global issues in agronomy, and analyze their advantages and disadvantages. 


\section{Addressing new questions}

107

108

109

110

111

112

113

114

115

116

117

118

119

120

121

122

123

124

125

126

127

Two examples of global issues in agriculture are presented below. We show that these issues create new research objectives and pose new research questions that need to be addressed by agricultural research institutes.

\subsection{Global nutrient management}

In the last decades, fertilizer applications to enhance crop production have been seen as agents of environmental damage, causing nitrate leaching, eutrophication and greenhouse gas emission. Their use was supported by the design of field-scale decision rules and crop models (van Ittersum and Donatelli 2003), and by the assessment of nutrient flows at catchment scale. However, recent concerns have emerged about the finite nature of global phosphorus (P) resources (Cordell et al. 2009; Van Vuuren et al. 2010) and the huge amount of reactive nitrogen (N) accumulating in the biosphere at global scale (Galloway et al. 2008). Both these phenomena are due to the massive use of mineral $\mathrm{N}$ and $\mathrm{P}$ fertilizers in agriculture (Bennett et al. 2001; Sutton et al. 2011; Tilman et al. 2002). Such issues raise new questions, concerning identification of the different drivers of global fertilizer use, for example (Sattari et al. 2012). Reports have indicated that nutrient cycle closure is relatively weak at the country scale, in many different contexts (Liu et al. 2008; Mishima et al. 2010; Senthilkumar et al. 2012a) due to both a large proportion of organic waste being not recycled to agricultural soils (Elser and Bennett 2011) and to a high degree of specialization and of spatial segregation of animal and feed production systems affecting nutrient flows and budgets (Grote et al. 2005; Liu et al. 2010; MacDonald et al. 2011; Naylor et al. 2005) and making it impossible to replace mineral fertilizer with animal manure (Senthilkumar et al. 2012b).

New research objectives are required to deal with this issue. Studies assessing the consequences of food/feed demand (e.g. the proportion of animal products in human diets, food losses, food chain design) on global nutrient flows are required. This would involve dynamic models simulating the 
effects of food diets on crop production requirements and ultimately on fertilizer use. It would also be necessary to assess the consequences of the spatial organization of global feed and animal production basins and to study the effects of livestock feeding regimes on changes in land use in regions of feed production (e.g. soy production in South America) and their environmental consequences. Finally, research needs to pay more attention to the possibilities for waste recycling (e.g., from the food industry or wastewater management) in agriculture, focusing, in particular, on the conditions required for the effective replacement of mineral fertilizers with organic materials derived from waste products.

\subsection{Global food security}

The food production dimension of food security is another important issue for agronomists. Crop yield increase rates are key parameters for foresight studies on food security (Paillard et al., 2010), and their values are very variable both spatially (Figure 2 ) and temporarily (Figure 3 ). In the past, crop production and its variability were studied at field scale by means of experiments and of crop models simulating the effect of cropping techniques on crop yield. However, tackling food production at a global scale requires significant changes in research objectives, particularly as concerns climate change. The effect of climate change on global food production has been investigated in many studies (Lobell and Burke 2009). Such studies require three types of data: (i) data on future climatic conditions, (ii) data on the effect of climatic variables on crop production, and (iii) data on the effect of climatic variable on land use and cropping practices. For illustration, data quantifying the effect of climate change on wheat yields were extracted from 90 published papers retrieved from the Web of Knowledge between 1991 and 2012, and were displayed in Figure 4. These data represent relative yield changes defined by $\mathrm{RCY}=100 *$ (future average yield - baseline average yield) $/$ baseline average yield, where "baseline average yield" and "future average yield" correspond to simulated yield values averaged over years for both baseline and future climatic scenarios. Simulated yields were generated using different types of crop models for different climate change scenarios in several 
countries. The median RCY reported in the 90 published papers ranged from $-4.5 \%$ (Spain) to $+15 \%$ (India) (Figure 4). The variability of RCY was very strong within a given country, especially in countries where the number of reported data was high. For example, RCY ranged from $-100 \%$ to $+90.8 \%$ in Australia and from $-97.6 \%$ to $+155.8 \%$ in USA. This result shows that simulated climate change impact on yield can be very different depending on the location, the considered crop models, and the climatic scenarios.

Contrary to data of types (i) and (ii), data on agricultural land use and cropping practices are scarce, particularly for larger scales. For this reason, the effects of climate change on crop production are usually estimated for potential yields only, and the effects of other limiting factors are rarely taken into account.

More generally, the global food security issue raises questions about the production capacities of various types of farming systems (organic, intensive, integrated etc.) and their ability to satisfy the demand for food. For instance, the ability of organic farming to feed the world has been much debated in recent years (de Ponti et al. 2012; Seufert et al. 2012; Badgley et al. 2007). Organic farming scenarios have been compared with conventional systems on the basis of crop yield ratios (organic vs. conventional) determined at the field scale for various sites. However, the ratio-based approach has several limitations. For example, it does not take into account the transition between current levels of organic farming (approximately $1 \%$ ) to a future $100 \%$ organic global farming system or the spatial interactions between organic and conventional cropping systems (e.g. the effects of conventional spraying on pest dynamics might indirectly provide pest control for organic cropping systems;(Norton et al. 2009; Ricci et al. 2009; Roschewitz et al. 2005; Thies and Tscharntke 1999). Organic farming extension raises questions about the effectiveness of legume $\mathrm{N}$ fixation, use of organic materials, and soil nutrient depletion to replace mineral fertilizer. The capacity of the current agricultural area to fix enough $\mathrm{N}$ to sustain crop production and the ability of organic farming to make use exclusively of soil $\mathrm{P}$ mining and $\mathrm{P}$ recycling without external $\mathrm{P}$ input from chemical 
fertilisers have not been precisely quantified (de Ponti et al. 2012; Doberman 2012). Therefore, the transition from conventional to organic land use might increase competition for nutrients derived from organic fertilizers at the regional scale (Nesme et al. 2012).

Besides the global food security issue raises questions about spatial distribution of crops and cropping systems at the global scale under scenarios of climate or farming system change. It also highlights the need to deal with regional questions, such as spatial interactions between farming systems in terms of nutrient availability or pest/enemy relationships and the scaling-up of such interactions.

Table 1 lists a series of new scientific questions for global agronomy, using the two examples presented above.

\section{Current knowledge and methods in agronomy: their utility and}

\section{limitations for addressing global issues}

Many agronomic studies worldwide still make use of surveys, experiments and modeling. An exhaustive analysis of the literature is impossible, as this would require the examination of tens of thousands of articles. However, a qualitative approach to the topics covered by agronomic research can nevertheless be attempted.

\subsection{Knowledge on how agroecosystems work}

Most agronomic studies are carried out at the field scale. It is easy to find examples of such studies in any issue of the major agronomy journals (Harunur Rashid et al. 2012; Krueger et al. 2012; Nakano et al. 2012). Many studies in the second half of the $20^{\text {th }}$ century focused on the effects of soil tillage, 
crop rotation, irrigation, fertilizer application, crop protection strategies, crop density, date of sowing and, of course, genotype. Over the last two decades, new variables have emerged, such as the effect of mixing species (Malezieux et al. 2008) or the use of new types of fertilizers (Cavanagh et al. 2011). Attention has also shifted onto new topics, such as nonfood uses of crop products and the impact of agriculture on environmental resources or ecosystem services (Otieno et al. 2011). These trends are a consequence of the diverse major challenges currently facing agriculture and the need for changes in agricultural systems, which may not in themselves be sufficient (Foley et al. 2011).

An increasing number of studies are comparing entire cropping systems rather than just a few sets of techniques (e.g., a few fertilizer doses and a few cultivars), through experiments, model simulations, or both (Rossing et al. 1997). For example (Farooq et al. 2011) considered the effects of conservation and conventional agriculture, whereas (Michos et al. 2012) compared organic, integrated and conventional orchards, in a similar way to (Reganold et al. 2001). Unlike experiments considering only a limited number of technical elements, cropping system studies acknowledge that the effect of a single technique cannot be reliably predicted if the other techniques of the cropping system are not taken into account (Doré et al. 1997). These studies aim to bridge the gap between simplified experiments and the real farming. However, the generic value of cropping system studies is decreased by the lack of specificity of cropping system names, such as "conventional systems", "organic systems" and "integrated systems" since many different practices are covered by such names.

More recently, agronomists have enlarged both their spatial and temporal scales of investigation. Some experiments are now also carried out at larger scales, particularly at the scale of the landscape. A few decades ago, agronomists began to address environmental issues, such as soil erosion and water pollution (Jones et al. 1990; Knickel 1990). They recently began studying the effects of land use or cropping patterns on ecological processes (Ricci et al. 2009; Thies et al. 2011). Over the same period, interest has increased in medium-term (e.g. several years; (Enfors et al. 2011) and long-term 
(e.g. several decades; (Yang et al. 2011) assessments of cropping systems, and this has led to some methodological progress (Brandt et al. 2010). Such changes in time scale are driven by the fact that many ecosystem services (e.g. carbon sequestration) must be considered over the long term, together with the anticipation that some effects of cropping systems are unlikely to be evident immediately, instead being expressed only after stabilization of the agroecosystem.

Models simulating the effects of cropping systems on agroecosystems from field to regional scale and from year to decades are of key importance for global agronomy. Such models would facilitate the assessment of effects of changes in agricultural systems, or the design of new agricultural systems. For instance, estimates of $\mathrm{N}_{2} \mathrm{O}$ emissions by the Tier 1 to Tier 3 methods (Eggleston et al. 2006) were used by the International Panel on Climate Change in their prospective studies dealing with greenhouse gas emission and climate change.

Another example is provided by the issue of fossil P reserve depletion, which may lead to a shortage of $\mathrm{P}$ fertilizer and a potential decrease in soil $\mathrm{P}$ availability at global scale. This raises questions about the effects of such decreases on long-term global food production. Recent studies have reported current or future soil P budgets (soil P input minus soil P output) on a $50 \mathrm{~km} \times 50 \mathrm{~km}$ grid, based on fertilizer use and livestock density statistics (MacDonald et al. 2011; Van Vuuren et al. 2010). However, there is a gap in our knowledge between these budgets on the one hand and the consequences in terms of global crop production on the other (Sattari et al. 2012). In the future, existing field-scale soil and crop models could be used to relate soil P budget to soil P availability (e.g. soil P concentration) in a large range of soil conditions and cropping systems (Messiga et al. 2012), and then to predict crop yields for some crop species as a function of soil P availability (Mollier et al. 2008) (Figure 5). Linking global scale P budgets and existing field-scale models would, therefore, be very useful for assessing the consequences of global current or future $\mathrm{P}$ fertilization practices in terms of global crop production. 
However, we have to push the limits of our current knowledge for addressing global issues. The various possible combinations of climate, soil and technical conditions do not receive equal amounts of attention in agronomic studies (for example, studies of "minor" crops, such as tuber or some cereal crops, are scarce, despite the possible regional importance of these crops in the diet of the population). This inequality partly reflects the differences in investment in agronomic research across the world. In addition, some of the crucial topics for addressing global issues have been largely neglected. For instance, studies on the effects of farming systems on pest dynamics across countries and continents are much rare than studies considering pest control at the field scale.

\subsection{Knowledge about farmers' practices and the factors driving them}

Agronomists have long studied farmers' practices. Research studies have investigated the interactions between the various practices and the factors driving farming practices (Fresco 1984; Collinson 2000). In these studies, a farm is seen as a place where a farmer coordinates different practices in a comprehensive and coherent way, to satisfy a set of goals. Studies on cropping system management and landscape management (e.g. slashing, field and hedgerow patterns, irrigation and drainage devices) have shown that complex processes underlie the decisions taken by farmers (Papy 2001) and that farmers' decisions regarding crop rotations and cropping plans, as well as crop management, can be formalized through decision rules and models (Cros et al. 2004; Aubry et al. 1998).

These studies have also highlighted the considerable diversity in farmers' goals and management practices. Agronomists have developed farm clustering methods to describe farm diversity at the regional scale. They have also developed and used user-friendly models to manage the rural landscape in a collective manner, to reduce run-off and erosion, for example (Joannon et al. 2006), or to introduce innovations in supply chains (Le Bail and Makowski 2004; Le Gal et al. 2008). Some of 
these models have been adopted as tools for collective training and scenario design (Souchère et al. 2010). Such models may be useful for discussing global scenarios of agricultural innovation.

\section{7}

Most of this research has been carried out at the farm and regional scales. However, information about farmers' practices is required at a larger scale to address global agricultural issues. For instance, although knowledge of land-use categories (forests, grasslands, crops) may be sufficient for the assessment of carbon sequestration, an in-depth knowledge of farmers' practices (fertilization rates and dates, grazing practices or soil tillage) may be required for the accurate estimation of greenhouse gas emissions at large scale (Stehfest and Bouwman 2006). Remote-sensing and largescale surveys are useful for describing current land use and farmers' practices (Mueller et al. 2012; Ramankutty et al. 2008). (Mignolet et al. 2004) used such surveys to assess changes in cropping patterns in the Seine basin in France $\left(95000 \mathrm{~km}^{2}\right)$ over a 30-year period, to assess the link between cropping systems and the nitrate content of the river water. They showed a gradual crop specialization in this area (Le Ber et al. 2006). However, it would be difficult to apply their protocol at a large scale. Expert knowledge may help to characterize cropping practices (Leenhardt et al. 2010; Sacks et al. 2010). The gathering of data on farmers' practices over large scales remains, however, a major challenge.

\section{Methods for addressing global issues in agronomy}

In this section, we present and discuss various methods for addressing global issues in agronomy. Their objectives, advantages and disadvantages are summarized in Table 2. 


\subsection{Experiments}

297 Experimentation is probably still the most popular method used by agronomists. Experiments form the foundations of most of the knowledge accumulated to date in agronomy (see Section 2.1). Experimental results may help to formulate general laws concerning the function of agroecosystems at global scale, but the definition of general laws from local experiments is not straightforward. In the past, too many agronomic experiments were conducted considering agroecosystems as a black box, without measuring internal variables. As a result, it was not possible to "understand the reasons behind" the observed responses (Garside and Bell 2011), and to discuss the validity of conclusions derived from observations.

Fortunately, agronomic experiments are increasingly making use of instrumentation, which is an advantage for studies of global issues as it allows agronomists to explore a wide range of conditions. Most of the experiments are carried out at field stations, but a growing number are carried out on real farms (Tueche and Hauser 2011; Kiba et al. 2012; Bertomeu 2012; Piepho et al. 2011). Some experimental studies are also based on farmers' practices, and make use of the diversity of these practices to develop a heuristic design, without experimental treatment (Delmotte et al. 2011). This approach takes into account the diversity of the farming conditions, which is absolutely essential for addressing global issues as the results obtained at field stations may not be consistent with those obtained on real farms. This may facilitate the prediction of agronomic results in areas in which few factorial experiments have been carried out.

315 Experimental results are of critical importance for global agronomy. In particular, cropping system databases including experimental results may lead to general conclusions based on the findings of large numbers of experiments, e.g. the Chinese database of (Hou et al. 2012). They may also help researchers to define theoretical principles concerning the functioning of agroecosystems on the basis of large numbers of scattered references, through comparative agronomy (Doré et al. 2011). 
However, agronomic experiments currently suffer from the limited development of integrated databases for addressing global issues. There are some databases in existence, e.g., based on public statistics (e.g., FAOSTAT), but they include few data for cropping systems or experimental results.

\subsection{Crop, global vegetation and land-use models}

Crop models can be used to explore the response of key agronomic and environmental variables, (e.g. crop yield or $\mathrm{N}$ losses) to climate, cropping system variables or societal changes (see Section 3.1). An interesting feature of these models is that they account for the effect of a wide range of agricultural practices (Brisson et al. 2003; Stockle et al. 2003). They can thus be used to represent and optimize management decisions, and to assess the impact of these decisions on crop production and environmental variables (Bergez et al. 2002). Some of these models can also be used to generate and assess crop management options (Dogliotti et al. 2005).

Dynamic crop models are frequently used to study the effect of climate change on crop yields (Brisson and Levrault 2010). For instance, 90 papers presenting model-based simulations of climate change effects on wheat yield were retrieved from the Web of Knowledge from 1991 to 2012 (Figure 3).

However, crop models are usually implemented at the field level, and their implementation at larger scales is problematic. A major problem is obtaining the input data necessary to run the crop model: physical input data (climate, soil characteristics and initial conditions) and data concerning crop management. Several methods have been proposed for estimating input values at large scales, including zoning, interpolation and remote sensing (Leenhardt et al. 2006), but the application of these techniques is not always possible and may lead to uncertain input values.

On the contrary, Global dynamic vegetation models (GDVM) are now frequently used to assess the 
regional or global impacts of climate changes on ecosystems. Unlike dynamic crop models, these

344 models generate an output that is regionally distributed over a regular grid and can thus be used to

345 draw maps at regional, national or continental scales. The ORCHIDEE model (Krinner et al. 2005) is an

346 example of a GDVM. This model calculates the energetic and hydrological budget of the soil and

347 vegetation continuum, together with the carbon and $\mathrm{N}$ cycles. Photosynthesis, phenology, the

348 allocation of carbon and nitrogen to the different organs, plant growth and mortality and the

349 decomposition of litter and soil organic matter are assessed with simple equations dependent on

350 various plant functional types. ORCHIDEE has been coupled to specific agricultural modules for

351 croplands (de Noblet-Ducoudré et al. 2004), to account for the characteristic phenology of such

352 anthropogenic ecosystems.

353 GDVM can be applied at local, regional or global scales over time scales extending from hours to

354 decades. The versatility of these models makes them very useful for regional assessments of the

355 impacts of climate change. However, GDVM have several limitations. Unlike dynamic crop models,

356 they generally simulate crop types (e.g., C3 and C4 crops), rather than crop species. These models do

357 not take into account agricultural practices and cannot be used to compare several cropping systems.

358 Moreover their high computation times make the implementation of classical uncertainty and

359 sensitivity techniques very difficult.

360 Species distribution models are frequently used to estimate the potential geographic distributions of

361 crop pests (Dupin et al. 2011). These estimations are based on local climatic conditions and pest

362 species requirements (e.g., optimal temperature for crop infection). Such models are frequently used

363 to draw maps of biological invasion risk at regional and global scales. These maps can be used to

364 assess future risks of yield and quality losses. However, the parameters of species distribution

365 models are difficult to estimate and the predictions of these models can be inaccurate (Dupin et al.

366 2011). 
Finally, land-use optimization models based on linear programming (LP) can also be used to address global issues. Linear programming has been recognized as an important tool for agricultural land-use exploration since the 1980s (de Wit et al. 1988). LP models can be used to explore land-use allocations optimizing agricultural, economic or environmental objectives at the farm regional and continental levels (van Ittersum et al. 1998). A LP model includes an objective function (to be minimized or maximized) and one or several constraints. In LP models developed for land-use exploration, the objective function may represent an economic, agricultural or environmental objective. LP models can be used to find an optimal solution (e.g. an optimal set of areas allocated to the production activities maximizing an objective function and satisfying the constraints included in the models). LP models are useful for exploring the effect of a change of objective and/or constraints (e.g. a stronger constraint on the total amount of pesticides applied) on agricultural land use in a region, country or continent. However, LP models have important limitations: they are static and cannot easily be used to study land-use change over time. Moreover, LP models are also known to generate nearly optimal solutions that can be very different from the optimal solution in terms of land-use allocation but very similar in terms of objective function values (Makowski et al. 2000, 2001).

\subsection{Yield gap analysis}

Yield gap analysis is a key method for addressing future food security issues at the global scale. A yield gap is defined as the difference between the potential yield value and the yield actually obtained by the farmer (Lobell et al. 2009). Yield gap values are useful for identifying geographic areas in which yields could be increased, for determining the main factors limiting yield and defining future research priorities (Casanova et al. 1999; Doré et al. 2008; Licker et al. 2010; Neumann et al. 2010; Prost et al. 2008). An analysis of yield gaps can thus help agronomists to determine where and 
how crop productivity might be increased, if necessary. Yield gap analysis comprises two main steps: yield gap estimation and the identification of factors explaining yield gap variability. Many studies have focused on calculating and analyzing yield gaps, but several methodological problems are encountered in attempts to apply this analysis at the global scale.

Four approaches have been proposed for estimating potential yields: i) crop model simulations (Brisson et al. 2010), ii) field experiments and yield contests (Lobell et al. 2009), iii) farmers' maximum yields (Lobell et al. 2009), iv) estimation from global crop datasets including yield values and climatic variables (Licker et al. 2010; Monfreda et al. 2008; Mueller et al. 2012). Crop model simulations are probably the most widely used (Lobell et al. 2009), but their implementation at the global scale is problematic. Crop models require a large number of input variables related to climate, soil characteristics and farmers' practices, and these variables are difficult to assess for large numbers of sites. In addition, scaling up the results of crop model simulations to derive potential yield estimates at the global scale is not straightforward. The maximum yields obtained by farmers and local experiments can be used to estimate potential yield locally, but this approach cannot be used directly at the global scale. In addition, the first two approaches cannot be used alone to calculate yield gaps: they require a separate source of information concerning the actual yields achieved by farmers.

Global crop yield databases can be used to estimate both potential yields and yield gaps at the global scale (Licker et al. 2010). This approach is powerful and offers new perspectives for the analysis of yield gaps at the global scale. However, the proposed technique for potential yield estimation requires the categorization of climatic variables into a small number of categories and the number of data in each category must exceed a certain minimum, for the calculation of yield percentiles. The proposed method could be extended to the estimation of potential yields and yield gaps from global crop datasets by means of quantile regression (Makowski et al., 2007). However, Figure 6 shows that the yield values estimated by these techniques are sensitive to the selected probability value. In this 
figure, wheat yield gaps were computed from the global yield database used by Licker et al. (2010).

417 Potential yields were computed by quantile regression for several probabilities ranging from 0.90 418 (estimated potential yields correspond to the $90^{\text {th }}$ percentiles of the yield data) to 0.995 (estimated potential yields correspond to the $99.5^{\text {th }}$ percentiles of the yield data). When the probability used for computing potential yield was set equal to 0.90 , the median yield gap over all wheat plots of the database was equal to $2.44 \mathrm{t} \mathrm{ha}^{-1}$ (Figure 6). The median yield gap was much higher when this probability was set to a higher value; it reached $3.54 \mathrm{t} \mathrm{ha}^{-1}$ when the probability was set equal to 0.95, and $4.9 \mathrm{t} \mathrm{ha}^{-1}$ when the probability was set equal to 0.99 (Figure 6). These results show that the conclusions of a yield gap analysis can be highly sensitive to the procedure used to estimate potential yields.

Other issues are the identification and ranking of limiting factors explaining yield gaps (Prost et al. 2008), the risk of confounding effects (i.e., the confusing roles of different variables due to correlations, Bakker et al. 2005), and the dynamic changes in yield gaps over time (Laborte et al. 2012). Yield gap may vary over time due to the effect of climate change on potential yields and changes in farmers' yields. Figure 3 shows the changes in farmers' wheat yields since the 1960s in France and Spain. These two countries display different patterns of yield trends and yield variability. In France, wheat yields reached a plateau in the mid-1990s. No such plateau has yet been reached in Spain, but the yield percentiles presented in Figure 3 show that between-year yield variability has increased in Spain since the 1980s and that yield values remain lower in Spain than in France. Several explanations relating to climate, input use and farmers' learning curves have recently been discussed as ways of interpreting famers' yield dynamics (Brisson et al. 2010; Laborte et al. 2012). However, the interpretation of farmers' yield dynamics remains a challenge, especially due to the high uncertainty in the estimated yield trends. This high uncertainty is illustrated in Figure 7 where the standard deviations of the estimated values of wheat yield yearly increase rates are shown for the 15 most 
important wheat producers in 2010 (FAOSTAT); standard deviations are often close to and even sometimes higher than the estimated values (Figure 7).

\subsection{Meta-analysis}

Meta-analysis could become a key method for determining general laws about the way in which agroecosystems work. Meta-analysis is a quantitative systematic review of the literature, with the application of a statistical treatment to the cumulative dataset. Most meta-analyses carried out to date have been performed in medical science (Borenstein et al. 2009). This approach has been applied, albeit less systematically, in other areas, such as ecology (Cardinale et al. 2006), and has sometimes been applied in animal science (Sauvant et al. 2008) and plant pathology (Rosenberg et al. 2004).

The meta-analysis framework provides an interesting alternative to dynamic crop models, because these models include several sources of uncertainty and their predictions are not always reliable (Barbottin et al. 2008; Makowski et al. 2009). When a large body of scientific data is available, metaanalysis appears to be a promising approach for assessing the agronomic and environmental performances of agricultural practices at the global scale. For example, meta-analysis could be used to assess the effect of a decrease in nitrogen application on $\mathrm{N}_{2} \mathrm{O}$ emission at the global scale, based on an analysis of an experimental dataset on $\mathrm{N}_{2} \mathrm{O}$ emissions around the world. Meta-analysis can also be used to study the global consequence of a change in cropping systems, such as the effects of organic cropping systems on crop yields and food production (de Ponti et al. 2012).

Meta-analysis is a powerful tool, but its value may be greatly decreased by the use of inappropriate techniques. Philibert et al. (2012) recently analyzed the quality of 73 meta-analyses carried out in agronomy. They found that the quality of meta-analyses was generally lower in agronomy than in 
medical science. Based on this quality assessment, the following recommendations were formulated:

i) the procedure used to select papers from scientific databases should be explained, ii) individual data should be weighted according to their level of precision when possible, iii) the heterogeneity of data should be analyzed with random-effect models, iv) sensitivity analysis should be carried out and v) the possibility of publication bias should be investigated.

\section{Conclusion}

The growth of the human population and increasing concerns about the global impact of agriculture are likely to lead to major changes in agronomic research in the next decade. As shown here, agricultural scientists will tend to study new topics (e.g. food security, global impact of agriculture activities on climate change and biodiversity) and to deal with new scales and new objectives. Agronomists have traditionally worked at the field scale and, to a lesser extent, at the farm and regional scales, but they are not yet used to working at the global scale.

Agronomists have developed a large range of methods and tools that may be of interest for addressing global issues. However, this toolbox is not entirely suitable for application to global issues. Most experiments and dynamic crop models are currently adapted to local issues (e.g., fertilization management, local yield predictions) and their outputs cannot be easily be scaled up. Other methods, such as global vegetation models, land-use models, and meta-analysis are likely to become increasingly widespread in the future. They will allow to assess the effects of cropping practices at a large scale and to study the impact of various agricultural activities on food security and the environment. However, global agronomy will face the difficult task of drawing up general, global laws about the way in which agroecosystems work. 
Agronomists have a good knowledge of farmers' practices, and of the changes in and drivers of these practices. They have shown that cropping practices result from many different determinants that could be described through decision rules and models. Knowledge about farmers' practices may be useful for the design of consistent scenarios of future, alternative cropping systems at the global 489 scale. Large databases on cropping systems would facilitate the design of such scenarios, but we still 490 lack reliable databases concerning farmers' practices (e.g. land use, fertilization, irrigation, sowing 491 dates). The situation is similar for the ecosystem services of agricultural activities, for which only a 492 few reference databases exist. 
Table 1: How global issues raise new scientific questions for agronomy, concerning nutrient management

and global food security, for example

\begin{tabular}{|c|c|c|c|c|}
\hline \multirow[b]{2}{*}{ Scale } & \multicolumn{2}{|c|}{ Issue 1: Nutrient management } & \multicolumn{2}{|c|}{ Issue 2: Food security } \\
\hline & Field, catchment & Global & Field, landscape & Global \\
\hline $\begin{array}{l}\text { Examples of } \\
\text { research topics }\end{array}$ & $\begin{array}{l}\text { Assessing the } \\
\text { effects of soil, } \\
\text { climate and crop } \\
\text { management on } \\
\text { nutrient } \\
\text { dynamics. } \\
\text { Assessing the } \\
\text { effects } \\
\text { landscape } \\
\text { characteristics on } \\
\text { nutrient flows }\end{array}$ & $\begin{array}{l}\text { Identifying and } \\
\text { assessing the } \\
\text { different drivers } \\
\text { of global nutrient } \\
\text { use. } \\
\text { Assessing the } \\
\text { opportunities for } \\
\text { nutrient recycling }\end{array}$ & $\begin{array}{l}\text { Assessing the } \\
\text { effects of crop } \\
\text { management and } \\
\text { landscape } \\
\text { characteristics on } \\
\text { crop yield. }\end{array}$ & $\begin{array}{l}\text { Understanding } \\
\text { global farming } \\
\text { adaptation to } \\
\text { climate change. } \\
\text { Scaling up results } \\
\text { from field-scale } \\
\text { yield-gap analysis. } \\
\text { Identifying which } \\
\text { levers can be used } \\
\text { and which should } \\
\text { not be used to } \\
\text { increase crop } \\
\text { production in a } \\
\text { range } \\
\text { situations. }\end{array}$ \\
\hline Examples & $\begin{array}{l}\text { Managing } \\
\text { nutrients }\end{array}$ & $\begin{array}{l}\text { Limiting global } \\
\text { use of fossil } \mathrm{P} \text { and }\end{array}$ & $\begin{array}{l}\text { Assessing and } \\
\text { improving field- }\end{array}$ & $\begin{array}{l}\text { Assessing the } \\
\text { global yield-gap of }\end{array}$ \\
\hline
\end{tabular}




\begin{tabular}{|c|c|c|c|c|}
\hline objectives & $\begin{array}{l}\text { maximize field } \\
\text { crop production } \\
\text { and to minimize } \\
\text { environmental } \\
\text { losses. } \\
\text { Designing } \\
\text { landscapes that } \\
\text { minimize } \\
\text { environmental } \\
\text { losses. }\end{array}$ & reactive $\mathrm{N}$. & $\begin{array}{l}\text { scale farming } \\
\text { system } \\
\text { productivity. } \\
\text { Assessing the role } \\
\text { of the different } \\
\text { limiting factors } \\
\text { (yield-gap } \\
\text { analysis at field } \\
\text { scale). }\end{array}$ & $\begin{array}{l}\text { different farming } \\
\text { systems under } \\
\text { scenarios of } \\
\text { climate change } \\
\text { and resource } \\
\text { scarcity and } \\
\text { paving the way } \\
\text { for regional, } \\
\text { continental and } \\
\text { global solutions. }\end{array}$ \\
\hline Methods & $\begin{array}{l}\text { Field } \\
\text { experiments, crop } \\
\text { and catchment } \\
\text { modeling }\end{array}$ & $\begin{array}{l}\text { Global-scale } \\
\text { modeling, } \\
\text { database } \\
\text { management. }\end{array}$ & $\begin{array}{l}\text { Field } \\
\text { experiments, crop } \\
\text { modeling. }\end{array}$ & $\begin{array}{l}\text { Global and } \\
\text { regional scale } \\
\text { crop modeling, } \\
\text { meta-analysis, } \\
\text { yield-gap analysis. }\end{array}$ \\
\hline Output & $\begin{array}{l}\text { Decision support } \\
\text { tools. }\end{array}$ & $\begin{array}{l}\text { Scenario } \\
\text { assessment. }\end{array}$ & $\begin{array}{l}\text { Decision support } \\
\text { tools. }\end{array}$ & $\begin{array}{l}\text { Scenario } \\
\text { assessment. }\end{array}$ \\
\hline
\end{tabular}

498

499 


\begin{tabular}{|c|c|c|c|}
\hline Method & Objective & Advantage & Disadvantage \\
\hline Experiments & $\begin{array}{l}\text { Understanding how } \\
\text { agroecosystems work }\end{array}$ & $\begin{array}{l}\text { Account for the } \\
\text { variability of climate, } \\
\text { soil and farming } \\
\text { conditions }\end{array}$ & $\begin{array}{l}\text { Future events (e.g. } \\
\text { climate change) cannot } \\
\text { easily be accounted } \\
\text { for; data gathering and } \\
\text { data analysis can be } \\
\text { difficult }\end{array}$ \\
\hline Dynamic crop models & $\begin{array}{l}\text { Simulating effects of } \\
\text { climate, soil, and } \\
\text { management variables } \\
\text { on crop production } \\
\text { and environment }\end{array}$ & $\begin{array}{l}\text { Account for a wide } \\
\text { range of climate, soil } \\
\text { and farming conditions }\end{array}$ & $\begin{array}{l}\text { Not easily applied at } \\
\text { large scales due to the } \\
\text { problem of input } \\
\text { estimation }\end{array}$ \\
\hline $\begin{array}{l}\text { Global dynamic } \\
\text { vegetation models }\end{array}$ & $\begin{array}{l}\text { Simulating soil, plant, } \\
\text { and climate } \\
\text { characteristics at } \\
\text { regional and/or global } \\
\text { scale }\end{array}$ & $\begin{array}{l}\text { Can be applied at local, } \\
\text { regional or global } \\
\text { scales for time scales } \\
\text { extending from hours } \\
\text { to decades }\end{array}$ & $\begin{array}{l}\text { Do not use a precise } \\
\text { description of cropping } \\
\text { systems }\end{array}$ \\
\hline Land-use optimization & Optimizing land use & $\begin{array}{l}\text { Can be applied at farm, } \\
\text { regional and }\end{array}$ & $\begin{array}{l}\text { May generate a wide } \\
\text { range of land-use }\end{array}$ \\
\hline
\end{tabular}




\begin{tabular}{|c|c|c|c|}
\hline models & & $\begin{array}{l}\text { continental scales. } \\
\text { Take various objectives } \\
\text { and constraints into } \\
\text { account }\end{array}$ & $\begin{array}{l}\text { allocations with similar } \\
\text { performances }\end{array}$ \\
\hline $\begin{array}{l}\text { Species distribution } \\
\text { models }\end{array}$ & $\begin{array}{l}\text { Predicting the } \\
\text { geographic distribution } \\
\text { of pests }\end{array}$ & $\begin{array}{l}\text { Take into account local } \\
\text { climatic conditions and } \\
\text { pest requirements }\end{array}$ & $\begin{array}{l}\text { Parameter estimation } \\
\text { can be difficult }\end{array}$ \\
\hline Yield-gap analysis & $\begin{array}{l}\text { Estimating yield gaps, } \\
\text { and ranking of yield- } \\
\text { limiting factors }\end{array}$ & $\begin{array}{l}\text { Useful: } \\
\text { - } \text { To identify the } \\
\text { geographic } \\
\text { areas in which } \\
\text { yields could be } \\
\text { increased, } \\
\text { To determine } \\
\text { the main } \\
\text { factors limiting } \\
\text { yield, } \\
\text { To define } \\
\text { future } \\
\text { research } \\
\text { priorities }\end{array}$ & $\begin{array}{l}\text { Require estimation of } \\
\text { potential yields } \\
\text { Ranking of limiting } \\
\text { factors may be highly } \\
\text { uncertain }\end{array}$ \\
\hline Meta-analysis & Drawing up of general & Assessment of & Not relevant when only \\
\hline
\end{tabular}




\begin{tabular}{|l|l|l|l|}
\hline & $\begin{array}{l}\text { laws on how } \\
\text { agroecosystems work }\end{array}$ & agronomic and & a few papers are \\
environmental & available for the topic \\
based on the statistical & performances of & of interest. \\
treatment of a & agricultural practices & Its value may be \\
database derived from & at large scales & greatly decreased by \\
& literature review & & the use of \\
& & & inappropriate \\
& & & techniques \\
\hline
\end{tabular}


Figure 1. The global impact of agriculture has recently become a major research topic, stressed by

507 the rapid growth of the world population. The total population in Malaysia has increased by 256

508 percent during the last 50 years. In the Kuala Lumpur region, the population had tripled from its 1980

509 level.

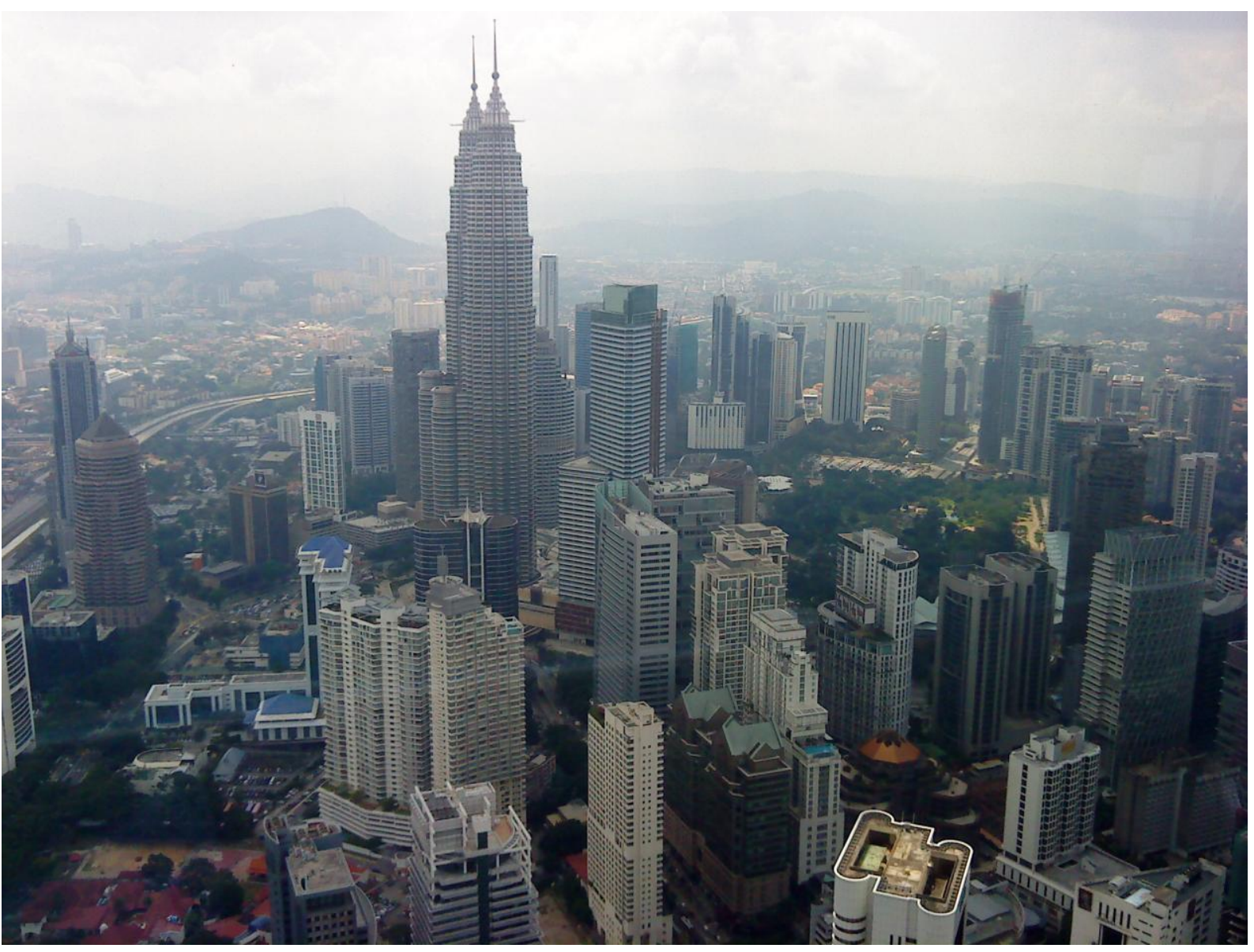


512 Figure 2. Map showing values of yearly increase rate of wheat yield in 2010 ( $\left.\mathrm{t} \mathrm{ha}^{-1} \mathrm{year}^{-1}\right)$. Wheat

513 yield increase rates were estimated for different countries from FAOSTAT wheat yield time series

514 using dynamic linear statistical models. For wheat in 2010, yearly increase rates range from negative

515 values (indicating yield decrease, in light yellow) to values higher than $+0.06 \mathrm{t} \mathrm{ha}^{-1}$ year ${ }^{-1}$ (dark green).

516 Yearly increase rate of crop yield is a key-parameter in foresight studies on food security.

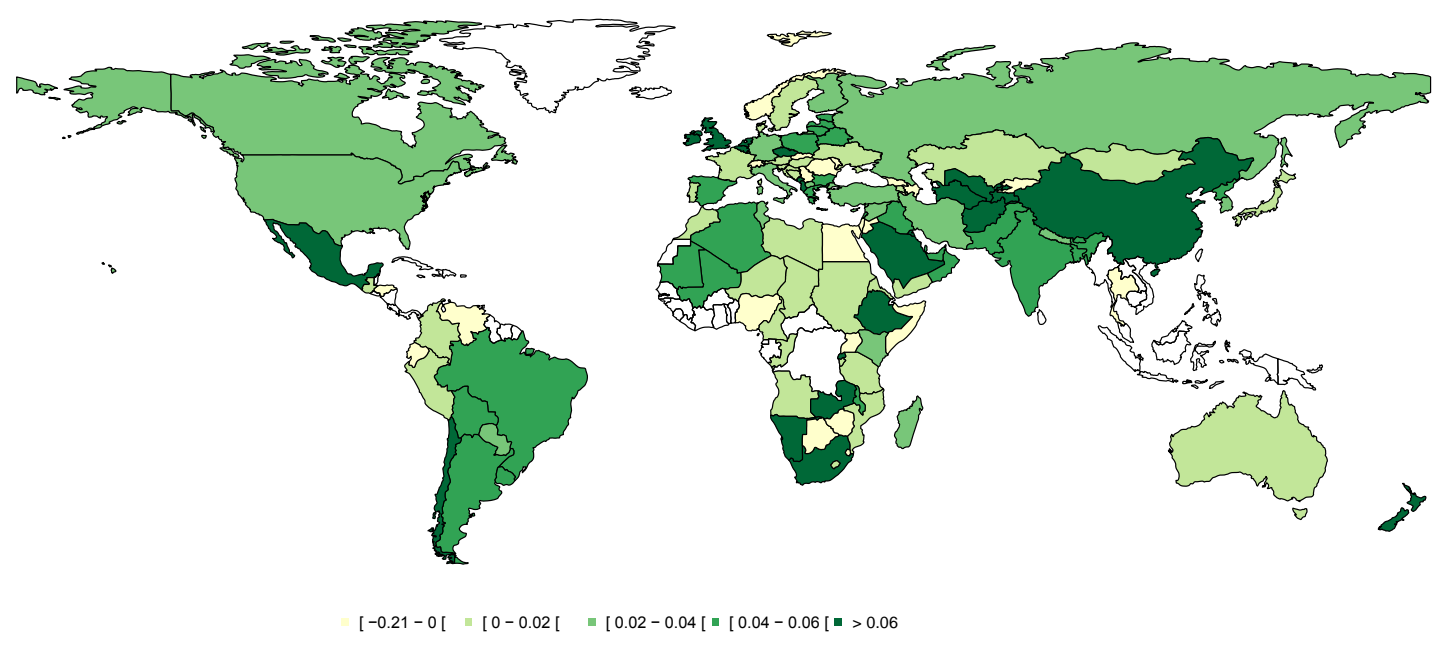


519 Figure 3. Yield data (thin lines), fitted trends (thick lines), and 5 and $95 \%$ yield percentiles (dotted 520 lines) in France and Spain. Data are from FAOSTAT. Fitted trends and percentiles were estimated with

521 stochastic volatility statistical models (Meyer and Yu 2000). Yield percentiles indicate the level of

522 between-year yield variability and show that the yield variability has increased since 1980 in Spain.

Yield in France (t ha-1)

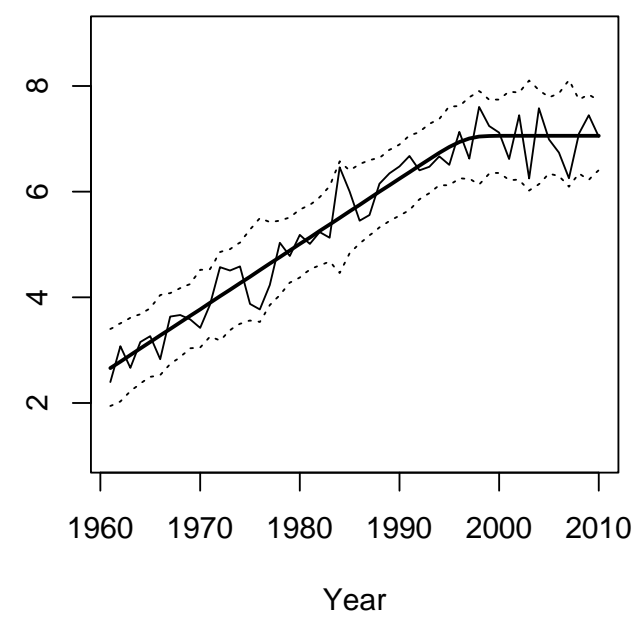

Yield in Spain (t ha-1)

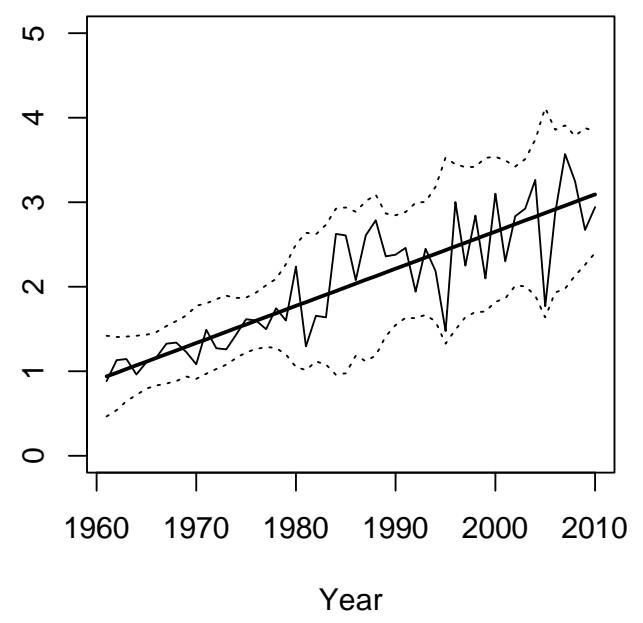


Figure 4. Distributions of relative change (\%) in wheat yield due to future climate change. Yield changes were computed from simulated data reported in 90 published papers for different countries. Relative yield change was defined by RCY $=100$ * (future average yield - baseline average yield) /

529 baseline average yield, where "baseline average yield" and "future average yield" correspond to yield values simulated by crop models and averaged over years for both baseline and future climatic scenarios. Each boxplot indicates the minimum, 1st quartile, median, 3rd quartile, and maximum of the RCY values available for each country (the numbers of available RCY values are given at the tops of the boxplots).

Relative yield change (\%)

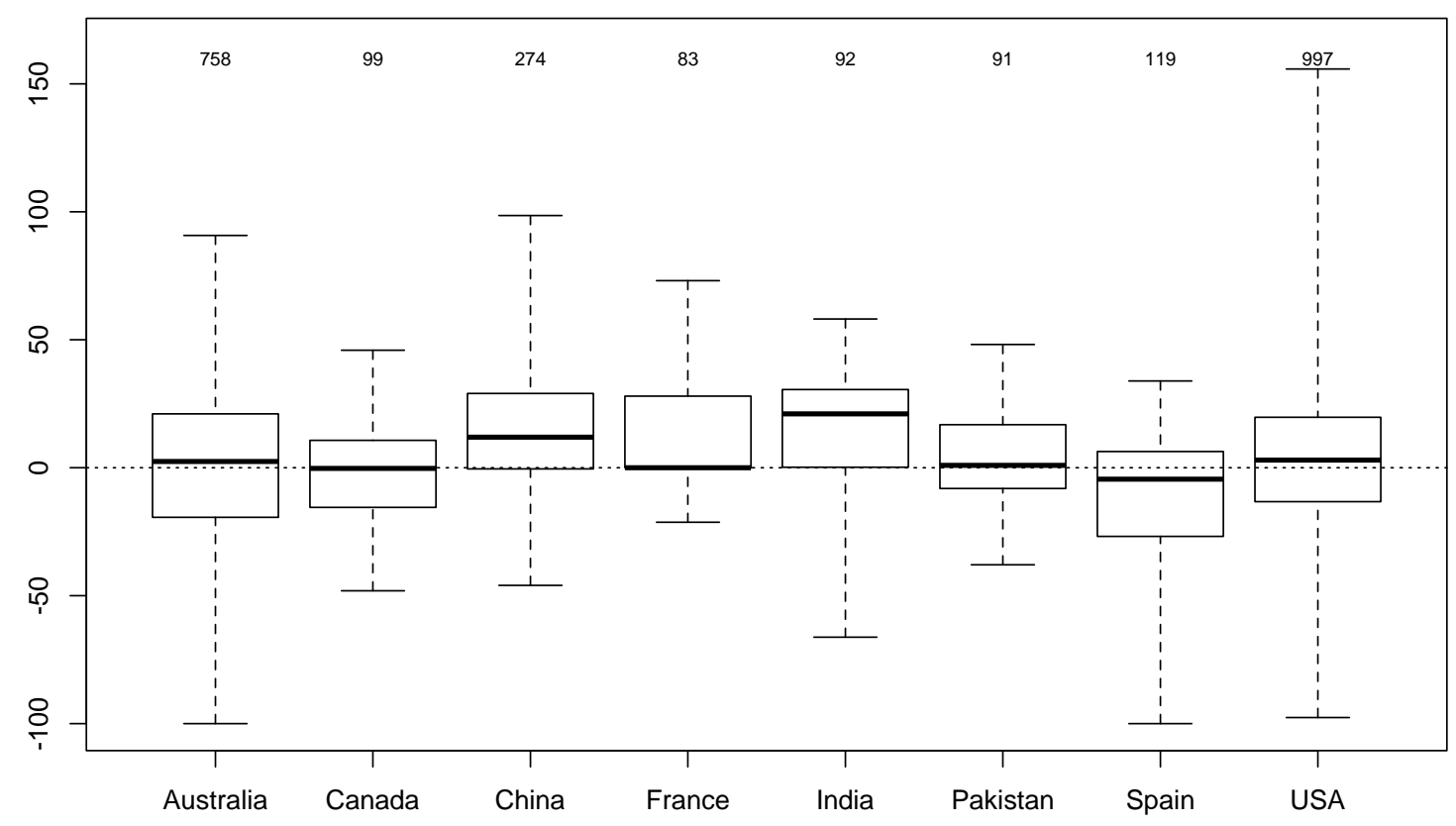


Figure 5. Using field-scale models simulating the effects of soil $P$ budget on soil $P$ availability (b) and the effects of soil $P$ availability on crop production (c) to relate global soil P budgets (a) to global crop production (d). Step (d) needs further research works.

539

540

(a) Global-scale map of soil P budget $(50 \mathrm{~km} \times 50 \mathrm{~km})$

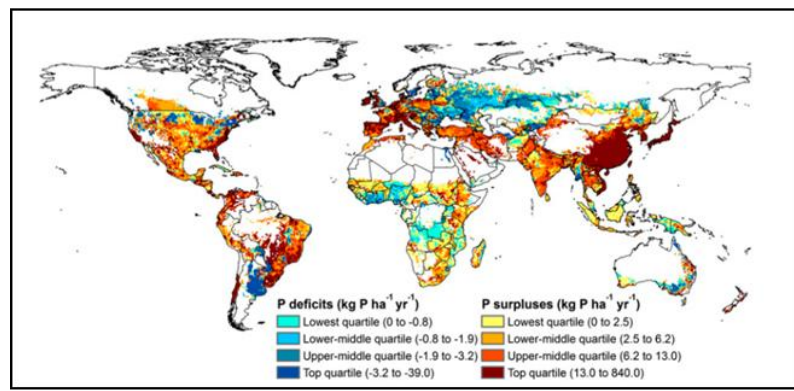

(MacDonald et al, 2011)

(d) Global-scale map of crop production

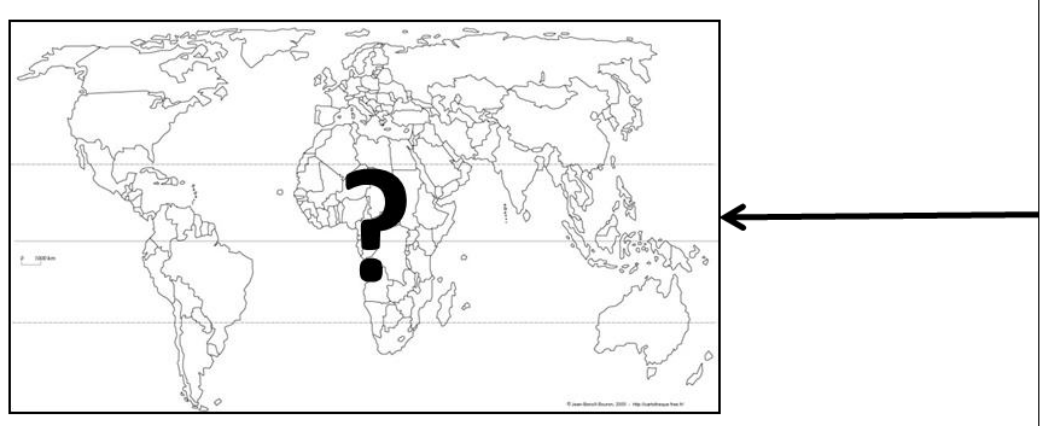

(b) Field-scale model relating soil $\mathrm{P}$ budget to soil $P$ availability

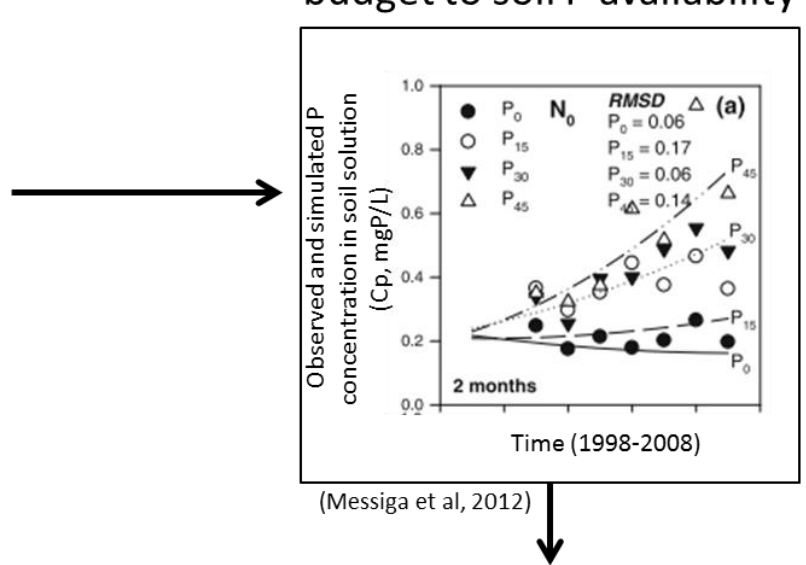

(c) Field-scale model relating soil P availability to crop production

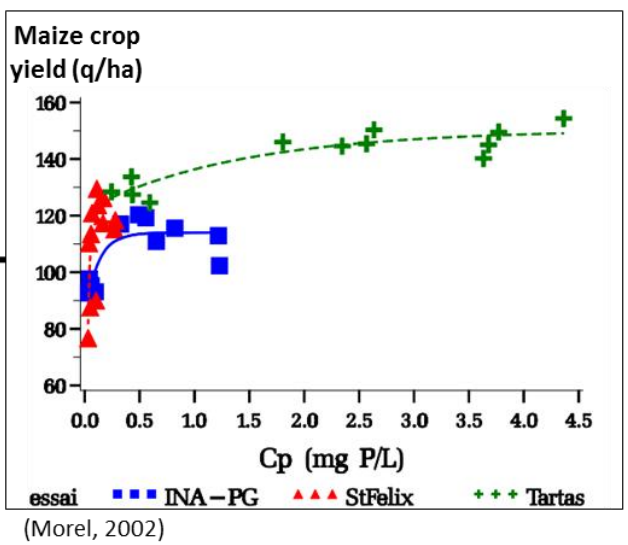

541 
Figure 6 . Sensitivity of wheat yield gaps to the probability chosen for estimating potential yields. The 549 continuous line indicates the median yield gaps over all wheat plots included in a global database at 550 the world scale (database used by Licker et al., 2010). The dashed lines indicate the 1st and 3rd 551 quartiles of the yield gaps over all wheat plots.

\section{Yield gap ( $t$ ha-1)}

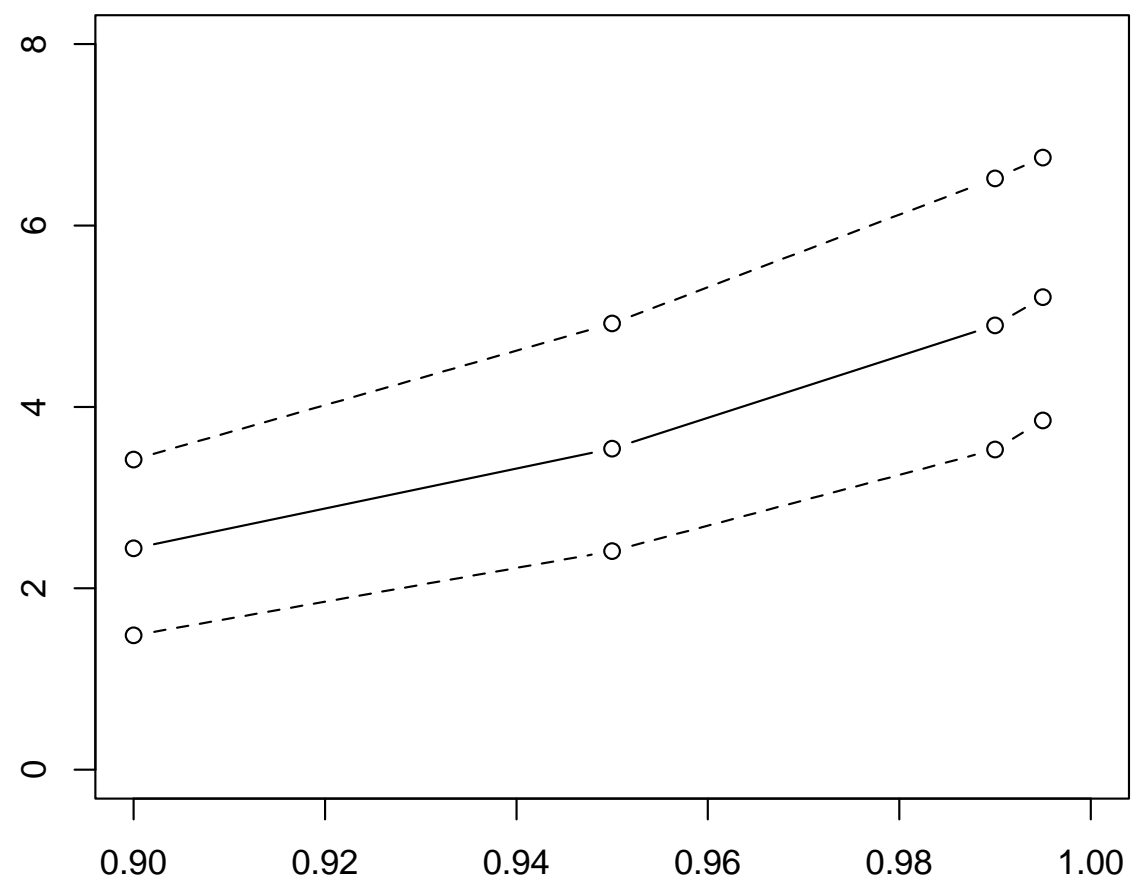

Probability used for estimating potential yield 
Figure 7. Estimated yearly increase rates of wheat yield $\left(\mathrm{t} \mathrm{ha}^{-1}\right.$ year $\left.{ }^{-1}\right)$ in 2010 and standard deviations of the estimated values. Results were obtained for the 15 countries with the highest wheat

558 productions in 2010, from a statistical analysis of yield time series (FAOSTAT).

559

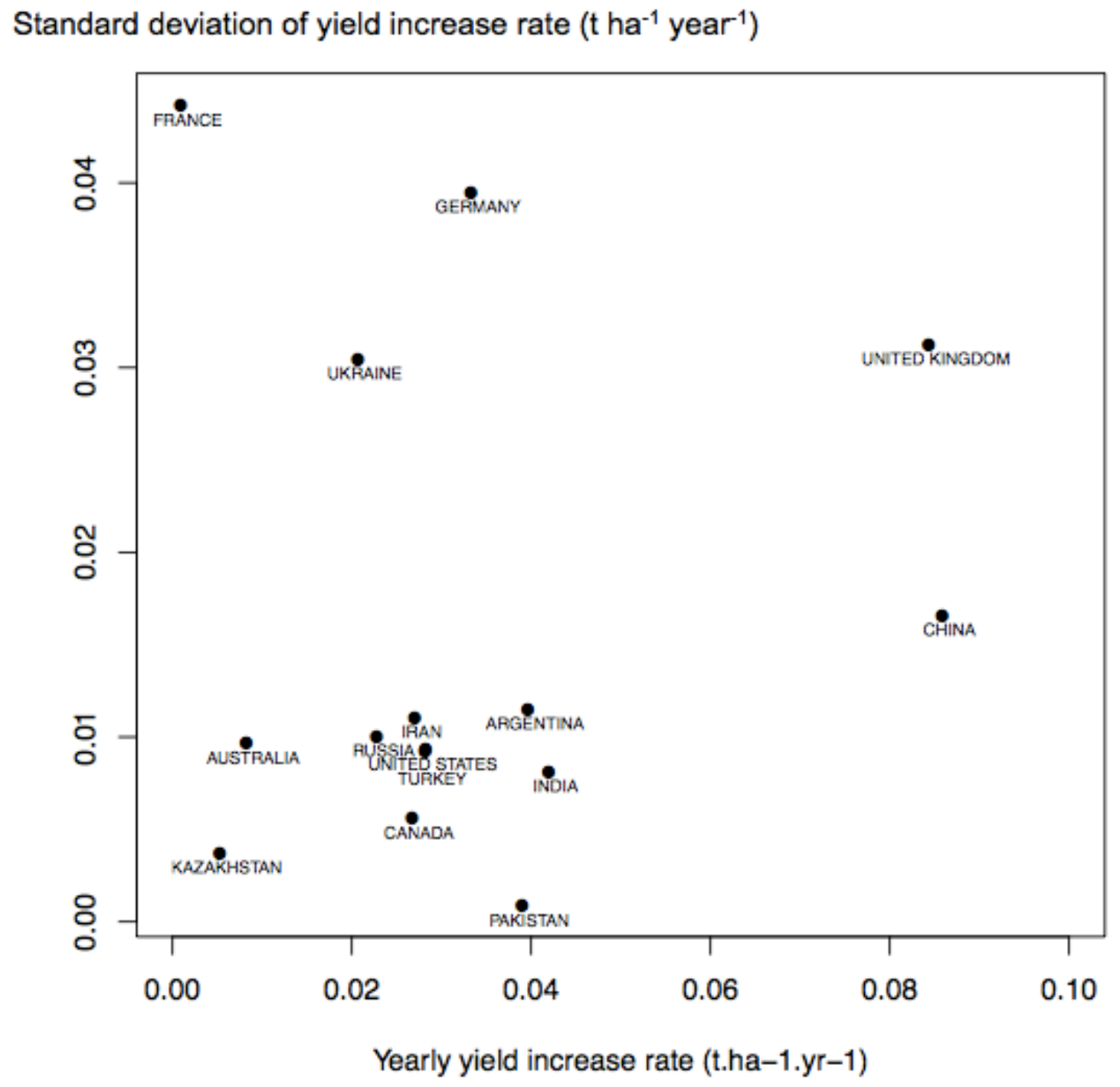

560

561 


\section{References}

Aubry C, Papy F, Capillon A (1998) Modelling decision-making processes for annual crop management. Agr Syst 56:45-65. doi:http://dx.doi.org/10.1016/S0308-521X(97)00034-6

Badgley C, Moghtader J, Quintero E, Zakem E, Chappell MJ, Avilés-Vazquez K, Samulon A, Perfecto I (2007) Organic agriculture and the global food supply. Renew Agr Food Syst 22:86-108. doi:http://dx.doi.org/10.1017/S1742170507001640

Bakker MM, Govers G, Ewert F, Rounsevell M, Jones R (2005) Variability in regional wheat yields as a function of climate, soil and economic variables: assessing the risk of confounding. Agr Ecosyst Environ 110:195-209. doi:http://dx.doi.org/10.1016/j.agee.2005.04.016

Barbottin A, Makowski D, Le Bail M, Jeuffroy M-H, Bouchard C, Barrier C (2008) Comparison of models and indicators for categorizing soft wheat fields according to their grain protein contents. Eur J Agron 29:159-183. doi:http://dx.doi.org/10.1016/j.eja.2008.05.004

Bennett EM, Carpenter SR, Caraco NF (2001) Human impact on erodable phosphorus and eutrophication: a global perspective. BioScience 51:227-234. doi:http://dx.doi.org/10.1641/0006-3568(2001)051\%5B0227:HIOEPA\%5D2.0.CO;2

Bergez J-E, Deumier J-M, Lacroix B, Leroy P, Wallach D (2002) Improving irrigation schedules by using a biophysical and a decisional model. Eur J Agron 16:123-135. doi:http://dx.doi.org/10.1016/S1161-0301(01)00124-1

Bertomeu M (2012) Growth and yield of maize and timber trees in smallholder agroforestry systems in Claveria, northern Mindanao, Philippines. Agroforest Syst 84:73-87. doi:10.1007/s10457011-9444-x

Borenstein M, Hedges LV, Higgins JPT, Rothstein HR (2009) Introduction to Meta-Analysis. Wiley, Hoboken NJ, USA

Brandt SA, Thomas AG, Olfert OO, Leeson JY, Ulrich D, Weiss R (2010) Design, rationale and methodological considerations for a long term alternative cropping experiment in the Canadian plain region. Eur J Agron 32:73-79. doi:http://dx.doi.org/10.1016/j.eja.2009.07.006

Brisson N, Gary C, Justes E, Roche R, Mary B, Ripoche D, Zimmer D, Sierra J, Bertuzzi P, Burger P, Bussière $F$, Cabidoche $Y-M$, Cellier $P$, Debaeke $P$, Gaudillère J-P, Hénault $C$, Maraux $F$, Seguin B, Sinoquet H (2003) An overview of the crop model Stics. Eur J Agron 18:309-332. doi:http://dx.doi.org/10.1016/S1161-0301(02)00110-7

Brisson N, Gate P, Gouache D, Charmet G, Oury F-X, Huard F (2010) Why are wheat yields stagnating in Europe? A comprehensive data analysis for France. Field Crop Res 119:201-212. doi:http://dx.doi.org/10.1016/j.fcr.2010.07.012

Brisson N, Levrault F (2010) Livre vert du projet CLIMATOR 2007-2010. ADEME, Paris

Cardinale BJ, Srivastava DS, Duffy JE, Wright JP, Downing AL, Sankaran M, Jouseau C (2006) Effects of biodiversity on the functioning of trophic groups and ecosystems. Nature 443. doi:doi:10.1038/nature05202

Casanova D, Goudriaan J, Bouma J, Epema GF (1999) Yield gap analysis in relation to soil properties in direct-seeded flooded rice. Geoderrma 91:191-216. doi:http://dx.doi.org/10.1016/S00167061(99)00005-1

Cavanagh A, Gasser MO, Labrecque M (2011) Pig slurry as fertilizer on willow plantation. Biomass Bioenerg 35:4165-4173. doi:http://dx.doi.org/10.1016/j.biombioe.2011.06.037

Collinson MP (2000) A history of farming system research. FAO and CABI publishing, Wallingford

Cordell D, Drangert J-O, White S (2009) The story of phosphorus: global food security and food for thought. Global Environ Chang 19:292-305. doi:http://dx.doi.org/10.1016/i.gloenvcha.2008.10.009

Cros MJ, Duru M, Garcia F, Martin-Clouaire R (2004) Simulating management strategies: the rotational grazing example. Agr doi:http://dx.doi.org/10.1016/j.agsy.2003.06.001 
de Noblet-Ducoudré N, Gervois S, Ciais P, Viovy N, Brisson N, Seguin B, Perrier A (2004) Coupling the soil-vegetation-atmosphere-transfer scheme ORCHIDEE to the agronomy model STICS to study the influence of croplands on the European carbon and water budgets. Agronomie 24:1-11. doi:http://dx.doi.org/10.1051/agro:2004038

de Ponti T, Rijk B, Van Ittersum MK (2012) The crop yield gap between organic and conventional agriculture. Agr Syst 108:1-9. doi:http://dx.doi.org/10.1016/i.agsy.2011.12.004

de Wit CT, van Keulen H, Seligman NG, Spharim I (1988) Application of interactive multiple goal programming techniques for analysis and planning of regional agricultural development. Agr Syst 26:211-230. doi:http://dx.doi.org/10.1016/0308-521X(88)90012-1

Delmotte S, Tittonel P, Mouret J-C, Hammond R, Lopez-Ridaura S (2011) On farm assessment of rice yield variability and productivity gaps between organic and conventional cropping systems under Mediterranean climate. Eur J Agron 35:223-236. doi:http://dx.doi.org/10.1016/i.eja.2011.06.006

Doberman A (2012) Getting back to the field. Nature 485:176-177. doi:doi:10.1038/485176a

Dogliotti S, van Ittersum MK, Rossing WAH (2005) A method for exploring sustainable development options at farm scale: a case study for vegetable farms in South Uruguay. Agr Syst 86:29-51. doi:http://dx.doi.org/10.1016/i.agsy.2004.08.002

Doré T, Clermont-Dauphin C, Crozat Y, David C, Jeuffroy M-H, Loyce C, Makowski D, Malezieux E, Meynard J-M, Valantin-Morison M (2008) Methodological progress in on-farm regional diagnosis. A review. Agron Sustain Dev 28:151-161. doi:http://dx.doi.org/10.1051/agro:2007031

Doré T, Makowski D, Malézieux E, Munier-Jolain N, Tchamitchian M, Tittonel P (2011) Facing up to the paradigm of ecological intensification in agronomy: Revisting methods, concepts and knowledge. Eur J Agron 34:197-210. doi:http://dx.doi.org/10.1016/i.eja.2011.02.006

Doré T, Sebillotte M, Meynard J-M (1997) A diagnostic method for assessing regional variation in crop yield. Agr Syst 54:169-188. doi:http://dx.doi.org/10.1016/S0308-521X(96)00084-4

Dupin M, Reynaud P, Jarošík V, Baker R, Brunel S, Eyre D, Pergl J, Makowski D (2011) Effects of training dataset characteristics on the performance of models for predicting the distribution of Diabrotica virgifera virgifera. PlosOne 6:1-11. doi:doi:10.1371/journal.pone.0020957

Eggleston S, Buendia L, Miwa K, Ngara T, Tanabe K (2006) 2006 IPCC Guidelines for National Greenhouse Gas inventories. Volume 4: Agriculture, Forestry and Other land Use. IPCC, Institute for Global Environmental Strategies, Hayama, Japan

Elser J, Bennett EM (2011) A broken biogeochemical cycle. Nature 478:29-31. doi:doi:10.1038/478029a

Enfors E, Barron J, Makurira H, Rockstrom J, Tumbo S (2011) Yield and soil system changes from conservation tillage in dryland farming: A case study from North Eastern Tanzania. Agr Water Manage 98:1687-1695. doi:http://dx.doi.org/10.1016/j.agwat.2010.02.013

Farooq M, Flower KC, Jabran K, Wahid A, Siddique KHM (2011) Crop yield and weed management in rainfed conservation agriculture. Soil Till Res 117:172-183. doi:http://dx.doi.org/10.1016/j.still.2011.10.001

Foley JA, Ramankutty N, Brauman KA, Cassidy ES, Gerber JS, Johnston M, Mueller ND, O'Connell C, Ray DK, West PC, Balzer C, Bennett EM, Carpenter SR, Hill J, Monfreda C, Polasky S, Rockström J, Sheehan J, Siebert S, Tilman D, Zaks DPM (2011) Solutions for a cultivated planet. Nature 478:337-342. doi:doi:10.1038/nature10452

Fresco LO (1984) Issues in farming systems research. Neth J Agr Sci 32:253-261

Galloway J, Townsend AR, Erisman JW, Bekunda M, Cai Z, Freney JR, Martinelli LA, Seitzinger SP, Sutton MA (2008) Transformations of the nitrogen cycle: recent trends, questions and potential solutions. Science 320:889-892. doi:DOI: 10.1126/science.1136674 
Garside AL, Bell MJ (2011) Growth and yield responses to amendments to the sugarcane monoculture: towards identifying the reasons behind the response to breaks. Crop Pasture Sci 62:776-789. doi:http://dx.doi.org/10.1071/CP11055

Grote U, Craswell E, Vlek P (2005) Nutrient flows in international trade: Ecology and policy issues. Environ Sci Policy 8:439-451. doi:http://dx.doi.org/10.1016/j.envsci.2005.05.001

Gruber N, Galloway JN (2008) An Earth-system perspective of the global nitrogen cycle. Nature 451:293-296. doi:doi:10.1038/nature06592

Harunur Rashid M, Murshedul Alam M, Rao AN, Ladha JK (2012) Comparative efficacy of pretilachlor and hand weeding in managing weeds and improving the productivity and net income of wet-seeded rice in Bangladesh. Field Crop Res 128:17-26. doi:http://dx.doi.org/10.1016/j.fcr.2011.11.024

Hou P, Gao Q, Xie R, Li S, Meng Q, Kirkby EA, Römheld V, Müller T, Zhang F, Cui Z, X. C (2012) Grain yields in relation to $\mathrm{N}$ requirement: Optimizing nitrogen management for spring maize grown in China. Field Crop Res 129:1-6. doi:http://dx.doi.org/10.1016/i.fcr.2012.01.006

Joannon A, Souchère V, Martin P, Papy $F(2006)$ Reducing runoff by managing crop localisation at the catchment level, considering agronomic constraints at farm level. Land Degrad Dev 17:467478. doi:10.1002/ldr.714

Jones AJ, Selley RA, Mielke LN (1990) Cropping and tillage options to achieve erosion control goals and maximum profit on irregular slopes. J Soil Water Conserv 45:648-653

Kiba DI, Zongo NA, Lompo F, Jansa J, Compaore E, Sedogo PM, E. F (2012) The diversity of fertilization practices affects soil and crop quality in urban vegetable sites of Burkina Faso. Eur J Agron 38:12-21. doi:http://dx.doi.org/10.1016/i.eja.2011.11.012

Knickel K (1990) Agricultural structural change impact on the rural environement. J Rural Stud 6:383393. doi:http://dx.doi.org/10.1016/0743-0167(90)90051-9

Krinner G, Viovy N, de Noblet-Ducoudrée N, Ogee J, Polcher J, Friedlingstein P, Ciais P, Sitch SP, C. (2005) A dynamic global vegetation model for studies of the coupled atmosphere-biosphere system. Global Biogeochem Cy 19:GB1015. doi:DOI: 10.1029/2003GB002199

Krueger K, Goggi AS, Mullen RE, Mallarino AP (2012) Phosphorus and potassium fertilization do not affect soybean storability. Agron J 104:405-414. doi:doi:10.2134/agronj2011.0156

Laborte A, de Bie K, Smaling EMA, Moya PF, Boling AA, van Ittersum MK (2012) Rice yields and yield gaps in Southeast Asia: past trends and future outlook. Eur J Agron 36:9-20. doi:http://dx.doi.org/10.1016/i.eja.2011.08.005

Le Bail M, Makowski D (2004) A model-based approach for optimizing segregation of soft wheat in country elevators. Eur J Agron 21:171-180. doi:http://dx.doi.org/10.1016/j.eja.2003.07.002

Le Ber F, Benoît M, Schott C (2006) Studying crop sequencies with CarrotAge, a HMM-based data mining software. $\quad$ Ecol Model 191:170-185. doi:http://dx.doi.org/10.1016/i.ecolmodel.2005.08.031

Le Gal PY, Lyne PWL, Meyer E, Soler LG (2008) Impact of sugarcane supply scheduling on mill sugar production: a South African case study. Agr Syst 96:64-74. doi:http://dx.doi.org/10.1016/j.agsy.2007.05.006

Leenhardt D, Angevin F, Biarnès A, Colbach N, Mignolet C (2010) Describing and locating cropping systems on a regional scale. A review. Agron Sustain Dev 30:131-138. doi:http://dx.doi.org/10.1051/agro/2009002

Leenhardt D, Wallach D, Le Moigne P, Guérif M, Bruand A, Casterad MA (2006) Using crop models for multiple fileds. In: Wallach D, Makowski D, Jones J (eds) Working with dynamic crop models. Elsevier, Amsterdam, pp 209-248

Licker R, Johnson M, Barford C, Foley JA, Kucharik CJ, Monfreda C, Ramankutty N (2010) Mind the gap: how do agricultural management explain the 'yield gap' of cropland around the world? Global Ecol Biogeogr 19:769-782. doi:DOI: 10.1111/j.1466-8238.2010.00563.x 
Liu J, You L, Amini M, Obersteiner M, Herrero M, Zehnder A, Yang H (2010) A high-resolution assessment on global nitrogen flows in cropland. P Natl Acad Sci USA 107:8035-8040. doi:10.1073/pnas.0913658107

Liu Y, Villalba G, Ayres RU, Schroder H (2008) Global phosphorus flows and environmental impacts from a consumption perspective. J Ind Ecol 12:229-247. doi:DOI: 10.1111/j.15309290.2008.00025.x

Lobell D, Burke M (2009) Climate change and food security: Adapting agriculture to a warmer world. Springer, Dordrecht

Lobell D, Burke M (2010) On the use of statistical models to predict crop yield responses to climate change. Agr Forest Meteorol 150:1443-1452. doi:http://dx.doi.org/10.1016/j.agrformet.2010.07.008

Lobell D, Cassman K, Field C (2009) Crop yield gaps: their importance, magnitudes, and causes. Annu Rev Env Resour 34:179-204. doi:DOI: 10.1146/annurev.environ.041008.093740

MacDonald G, Bennett EM, Potter PA, Ramankutty N (2011) Agronomic phosphorus imbalances across the world's croplands. P Natl Acad Sci USA 108:3086-3091. doi:10.1073/pnas.1010808108

Makowski D, Doré T, Monod H (2007) A new approach to analyze relationships between yield components using boundary lines. Agronomy for Sustainable Development 27:119-128. doi: 10.1051/agro:2006029

Makowski D, Hendrix EMT, van Ittersum MK, Rossing WAH (2000) A framework to study nearly optimal solutions of linear programming models developed for agricultural land use exploration. Ecol Model 131:65-77. doi:http://dx.doi.org/10.1016/S0304-3800(00)00249-0

Makowski D, Hendrix EMT, van Ittersum MK, Rossing WAH (2001) Generation and presentation of nearly optimal solutions for mixed-integer linear programming, applied to a case in farming system design. Eur J Oper Res 132:425-438. doi:http://dx.doi.org/10.1016/S03772217(00)00134-X

Makowski D, Tichit M, Guichard L, van Keulen H, Beaudoin N (2009) Measuring the accuracy of agroenvironmental indicators. J Environ Manage 90:S139-S146. doi:http://dx.doi.org/10.1016/j.jenvman.2008.11.023

Malezieux E, Crozat Y, Dupraz C, Laurans M, Makowski D, Ozier-Lafontaine H, Rapidel B, De Tourdonnet S, Valantin-Morison M (2008) Mixing plant species in cropping systems: concepts, tools and models. A review. Agron Sustain Dev 29:43-62. doi:10.1051/agro:2007057

Messiga AJ, Ziadi N, Bélanger G, Morel C (2012) Process-based mass-balance modelling of soil phosphorus availability in a grassland fertilized with $N$ and P. Nutr Cycl Agroecosys 92:273287. doi:10.1007/s10705-012-9489-x

Meyer R, Yu J (2000) BUGS for a Bayesian analysis of stochastic volatility models. Economet J 3:198215. doi:DOI: $10.1111 / 1368-423 X .00046$

Michos MC, Mamolos AP, Menexes GC, Tsatsarelis CA, Tsirakoglou VM, Kalburtji KL (2012) Energy inputs, outputs and greenhouse gas emissions in organic, integrated and conventional peach orchards. Ecol Indic 13:22-28. doi:http://dx.doi.org/10.1016/i.ecolind.2011.05.002

Mignolet C, Schott C, Benoit M (2004) Spatial dynamics of agricultural practices on a basin territory: a retrospective study to implement models simulating nitrate flow. The case of the Seine basin. Agronomie 24:219-236. doi:10.1051/agro:2004015

Mishima S, Endo A, Kohyama K (2010) Recent trends in phosphate balance nationally and by region in Japan. Nutr Cycl Agroecosys 86:69-77. doi:10.1007/s10705-009-9274-7

Mollier A, de Willigen P, Heinen M, Morel C, Schneider A, Pellerin S (2008) A two dimensional simulation model of phosphorus uptake including crop growth and P-response. Ecol Model 210:453-464. doi:10.1007/0-306-47624-X_293 
Monfreda C, Ramankutty N, Foley JA (2008) Farming the planet: 2. Geographic distribution of crop areas, yields, physiological types, and net primary production in the year 2000. Global Biogeochem Cy 22:GB1022. doi:DOI: 10.1029/2007GB002947

Mueller ND, Gerber JS, Johnston M, Ray DK, Ramankutty N, Foley JA (2012) Closing yield-gaps through nutrient and water management. Nature 490:254-257. doi:doi:10.1038/nature11420

Nakano H, Morita S, Kitagawa H, Wada H, Takahashi M (2012) Grain yield response to planting density in forage rice with a large number of spikelets. Crop Sci 52:345-350. doi:10.2135/cropsci2011.02.0071

Naylor R, Steinfeld H, Falcon W, Galloway J, Smil V, Bradford E, Adler J, Mooney H (2005) Losing the links between livestock and land. Science 310:1621-1622. doi:DOI: 10.1126/science.1117856

Nesme T, Toublant M, Mollier A, Morel C, Pellerin S (2012) Assessing phosphorus management among organic farming systems: a farm input, output and budget analysis in Southwestern France. Nutr Cycl Agroecosys 92:225-236. doi:10.1007/s10705-012-9486-0

Neumann K, Verburg PH, Stehfest E, Müller C (2010) The yield gap of global grain production: A spatial analysis. Agr Syst 103:316-326. doi:http://dx.doi.org/10.1016/j.agsy.2010.02.004

Norton L, Johnson P, Joys A, Stuart R, Chamberlain D, Feber R, Firbank L, Manley W, Wolfe M, Hart B, Mathews F, Macdonald D, Fuller RJ (2009) Consequences of organic and non-organic farming practices for field, farm and landscape complexity. Agr Ecosyst Environ 129:221-227. doi:http://dx.doi.org/10.1016/j.agee.2008.09.002

Otieno M, Woodcock BA, Wilby A, Vogiatzakis IN, Mauchline AL, Gikungu MW, Potts SG (2011) Local management and landscape drivers of pollination and biological control services in a Kenyan agro-ecosystem. Biol Conserv 144:2424-2431. doi:http://dx.doi.org/10.1016/i.biocon.2011.06.013

Paillard S, Treyer S, Dorin B (2010) Agrimonde : scénarios et défis pour nourrir le monde en 2050. Editions Quae, Paris

Papy $F$ (2001) Interdépendance des systèmes de culture dans l'exploitation agricole. In: Malézieux $E$, Trébuil G, Jaeger $M$ (eds) Modélisation des agro-écosystèmes et aide à la décision. Cirad-Inra edn. INRA-CIRAD, Montpellier, pp 51-74

Parry ML, Canziani OF, Palutikof JP, van der Linden PJ, Hanson CE (2007) Contribution of working group II to the fourth assessment report of the intergovernmental panel on climate change. Cambridge University Press, Cambridge, United Kingdom and New York, USA.

Philibert A, Loyce C, Makowski D (2012) Assessment of the quality of the meta-analysis in agronomy. Agriculture, Ecosystem and Environment 148:72-82. doi:10.1016/j.agee.2011.12.003

Philibert A, Loyce C, Makowski D (2013) Quantifying uncertainties in $\mathrm{N}_{2} \mathrm{O}$ emission due to $\mathrm{N}$ fertilizer application in cultivated areas. PlosOne 7. doi:doi:10.1371/journal.pone.0050950

Piepho HP, Richter C, Spilke J, Hartung K, Kunick A, Thöle H (2011) Statistical aspects of on-farm experimentation. Crop Pasture Sci 62:721-735. doi:http://dx.doi.org/10.1071/CP11175

Prost L, Makowski D, Jeuffroy M-H (2008) Comparison of stepwise selection and Bayesian model averaging for yield gap analysis. Ecol Model 219:66-76. doi:http://dx.doi.org/10.1016/i.ecolmodel.2008.07.026

Ramankutty N, Evan AT, Monfreda C, Foley JA (2008) Farming the planet: 1. Geographic distribution of global agricultural lands in the year 2000. Global Biogeochem Cy 22:GB1003. doi:10.1029/2007GB002952

Reganold JP, Glover JD, Andrews PK, Hinman HR (2001) Sustainability of three apple production systems. Nature 410:926-929. doi:doi:10.1038/35073574

Ricci B, Franck P, Toubon JF, Bouvier J-C, Sauphanor B, Lavigne C (2009) The influence of landscape on insect pest dynamics: a case study in southeastern France. Landscape Ecol 24:337-349. doi:10.1007/s10980-008-9308-6 
Roschewitz I, Hücker M, Tscharntke T, Thies C (2005) The influence of landscape context and farming practices on parasitism of cereal aphids. Agr Ecosyst Environ 108:218-227. doi:http://dx.doi.org/10.1016/i.agee.2005.02.005

Rosenberg MS, Garrett KA, Su Z, Bowden RL (2004) Meta-analysis in plant pathology: synthesizing research results. Phytopathology 94:1013-1017. doi:doi: 10.1094/PHYTO.2004.94.9.1013.

Rossing WAH, Meynard J-M, van Ittersum MK (1997) Model-based explorations to support development of sustainable farming systems: case studies from France and the Netherlands. Eur J Agron 7:271-283. doi:http://dx.doi.org/10.1016/S1161-0301(97)00042-7

Sacks WJ, Deryng D, Foley JA, Ramankutty N (2010) Crop planting date: an analysis of global patterns. Global Ecol Biogeogr 19:607-620. doi:DOI: 10.1111/j.1466-8238.2010.00551.x

Sattari SZ, Bouwman AF, Giller KE, Van Ittersum MK (2012) Residual soil phosphorus as the missing piece in the global phosphorus crisis puzzle. P Natl Acad Sci USA 109:6348-6353. doi:10.1073/pnas.1113675109

Sauvant D, Schmidely P, Daudin JJ, St-Pierre NR (2008) Meta-analyses of experimental data in animal nutrition. Animal 2:1203-1214. doi:doi:10.1017/S1751731108002280

Senthilkumar K, Nesme T, Mollier A, Pellerin S (2012a) Conceptual design and quantification of phosphorus flows and balances at the country scale: The case of France. Global Biogeochem Cy 26:GB2008. doi:doi:10.1029/2011GB004102

Senthilkumar K, Nesme T, Mollier A, Pellerin S (2012b) Regional-scale phosphorus flows and budgets within France: The importance of agricultural production systems. Nutr Cycl Agroecosys 92:225-236. doi:10.1007/s10705-011-9478-5

Seufert V, Ramankutty N, Foley JA (2012) Comparing the yields of organic and conventional agriculture. Nature 485:229-232. doi:doi:10.1038/nature11069

Souchère V, Millair L, Echeverria J, Bousquet F, Le Page C, Etienne M (2010) Co-constructing with stakeholders a role-playing game to initiate a collective management of erosive runoff risks at watershed scale. Environ Modell Softw 25:1359-1370. doi:http://dx.doi.org/10.1016/j.envsoft.2009.03.002

Spiertz H (2012) Avenues to meet food security. The role of agronomy on solving complexity in food production and resource use. Eur J Agron 43:1-8. doi:http://dx.doi.org/10.1016/j.eja.2012.04.004

Stehfest $\mathrm{E}$, Bouwman L (2006) $\mathrm{N}_{2} \mathrm{O}$ and $\mathrm{NO}$ emission from agricultural fields and soils under natural vegetation: summarizing available measurement data and modeling of global annual emissions. Nutr Cycl Agroecosys 74:207-228. doi:10.1007/s10705-006-9000-7

Stockle CO, Donatelli M, Nelson R (2003) CropSyst, a cropping systems simulation model. Eur J Agron 18:289-307. doi:http://dx.doi.org/10.1016/S1161-0301(02)00109-0

Sutton MA, Oenema O, Erisman JW, Leip A, van Grinsven H, Winiwarter W (2011) Too much of a good thing. Nature 161:159-161. doi:doi:10.1038/472159a

Thies C, Haenke S, Scherber C, Bengtsson J, Bommarco R, Clement LW, Ceryngier P, Dennis C, Emmerson M, Gagic V, Hawro V, Liira J, Weisser WW, Winqvist C, Tscharntke T (2011) The relationship between agricultural intensification and biological control: experimental tests across Europe. Ecol Appl 21:2187-2196. doi:10.1890/10-0929.1

Thies C, Tscharntke T (1999) Landscape structure and biological control in agroecosystems. Science 285:893-895. doi:DOI: 10.1126/science.285.5429.893

Tilman D, Gassman KG, Matson PA, Naylor R, Polasky S (2002) Agricultural sustainability and intensive production practices. Nature 418:671-677. doi:doi:10.1038/nature01014

Tscharntke T, Clough Y, Wanger TC, Jackson L, Motzke I, Perfecto I, Vandermeer J, Whitbread A (2012) Global food security, biodiversity conservation and the future of agricultural intensification. Biol Conserv 151:53-59. doi:http://dx.doi.org/10.1016/j.biocon.2012.01.068 
Tueche JR, Hauser S (2011) Maize (Zea mays L.) yield and soil physical properties as affected by the previous plantain cropping systems, tillage and nitrogen application. Soil Till Res 115:88-93. doi:http://dx.doi.org/10.1016/i.still.2011.07.004

van Ittersum MK, Donatelli M (2003) Modeling cropping systems: highlights of the symposium and preface to the special issues. Eur J Agron 18:187-197. doi:http://dx.doi.org/10.1016\%2fS1161-0301(02)00104-1

van Ittersum MK, Rabbinge R, van Latesteijn HC (1998) Exploratory land use studies and their role in strategic policy making. Agr Syst 58:309-330. doi:http://dx.doi.org/10.1016/S0308521X(98)00033-X

Van Vuuren DP, Bouwman AF, Beusen AHW (2010) Phosphorus demand for the 1970-2100 period: a scenario analysis of resource depletion. Global Environ Chang 20:428-439. doi:http://dx.doi.org/10.1016/j.gloenvcha.2010.04.004

Vereijken P (1997) A methodical way of prototyping integrated and ecological arable farming systems (I/EAFS) in interaction with pilot farms. Eur J Agron 7:235-250. doi:http://dx.doi.org/10.1016/S0378-519X(97)80029-3

Yang YX, Li PR, Zhang SL, Sun BH, Chen XP (2011) Long-term-fertilization effects on soil organic carbon, physical properties, and wheat yield of a loess soil. J Plant Nutr Soil Sc 174:775-784. doi:DOI: 10.1002/jpln.201000134 